\title{
Metaphors we (De)Legitimize by: Patterns of Metaphor Use in The Economist
}

\author{
Rahman Sahragard \\ Department of Foreign Languages \& Linguistics, Shiraz University \\ Shiraz, 71964-85115, Iran \\ Tel: 98-711-613-4517 Email: rsahragard@rose.shirazu.ac.ir \\ Alireza Rasti (Corresponding author) \\ Department of Foreign Languages \& Linguistics, Shiraz University \\ Shiraz, 71964-85115, Iran \\ Tel: 98-711-613-4517 Email:alirezarasti77@gmail.com
}

Received: 28-12-2013

doi:10.7575/aiac.ijalel.v.3n.3p.90
Accepted: 29-01-2014

Published: 01-05-2014

\begin{abstract}
The present research is a follow-up to another study (Rasti \& Sahragard, 2012) with an exclusive focus on political metaphor in general and specifically its (de)legitimatory role in the British paper The Economist. The Western paper takes an explicit sanctions-supportive stance on Iran's nuclear issue. With an eye to spotting instances of political metaphor in the said paper, the researchers, in the process of analyzing the data, which included 30 argumentative and expository articles taken from the British paper within two time frames - the first spanning 2005-2006 and the second encompassing data from 2012 and the beginning of 2013, came up with a superordinate metaphorical pattern i.e., $I R A N$ AS A HUMAN and its concomitant submetaphors i.e., IRAN AS A RACER/PLAYER, IRAN AS A BUSINESSMAN, IRAN AS A SUFFERER, and IRAN AS A SUSPECT/CULPRIT (for the first phase) and IRAN AS A WRONGDOER, IRAN AS A PATIENT and IRAN AS AN UNWANTED GUEST/A TRESPASSOR (as far as the second phase was concerned). The study concludes with the insight that the Western newspaper, among other things, stylistically and rhetorically employs and manipulates the metaphorical scenarios to justify and highlight the force and effectiveness of the West-backed sanctions against Iran and to render the country's nuclear plans as illicit and unwarranted.
\end{abstract}

Keywords: Conceptual Metaphor Theory; (De)legitimation; The Economist; Iran's nuclear program; Sanctions.

\section{Background and objectives}

The Economist, as a Western quality paper, takes an explicit stance vis-à-vis Iran's nuclear power program. In the majority of articles on the news and recent developments of the country, the paper is concerned with and about 'a nuclear Iran' and, among the proposed Western 'options on the table', it goes for applying (harsher) sanctions against a country it deems as undeserved of having a nuclear technology for better or worse:

... it is clear by now that relying on talk alone to stop Iran from going nuclear has failed. It is time to go to the UN Security Council and try sanctions. (The Economist, June 1, 2006, p.3).

Even in the middle of the relentless hue and cry of the American hawks and Israeli warmongers with regards to launching a 'pre-emptive strike' on the country's nuclear facilities (a euphemistic expression referring to post-eleventhSeptember events brought off by the Western front in Iraq and Afghanistan), the editorial board of the newspaper have mostly assumed an air of peacefulness and insisted solely on the 'crippling' force of sanctions, arguing that war will not stop Iran from pursuing its nuclear plans but may make it more determined in resuming what it sees as an inalienable right of its own. This is evident time and time again in the metadiscourse of the aforementioned paper:

This newspaper has favoured sanctions because an Israeli assault might start a regional conflagration, dragging in America - and even then might not succeed. (The Economist, January 21, 2012, p.1).

A previous study conducted on the data gleaned from The Economist (See Rasti \& Sahragard, 2012) revealed a host of linguistic, stylistic, and rhetorical moves employed by the paper in legitimating its advocated policy of applying more pressure on the country and delegitimating Iran's favorite course of action, that is, its doggedly following its nuclear dreams (See the discussion section of the said investigation).

Based on the findings of the previous study, the present research aims at exploring, in greater detail, one specific strategy manipulatively used by the British newspaper in fulfilling its goal of coloring the reader' views regarding Iran's nuke activities i.e., the use of metaphor. Apart from probing more deeply into this linguistic category, unlike the 
original research, this study further sets out to approach the function of the metaphorical patterns deduced in the data from a different perspective i.e., to examine the justificatory side to the metaphor use in The Economist. In the previous article, the focus was, inter alia, on the representational (i.e., referential and predicational) potentialities of this analytic tool. In other words, the original study was mostly concerned with laying bare the possible black and white image of the Iranian camp at large in the newspaper.

A number of studies with different (inter)disciplinary orientations have dealt, one way or another, with the issue of metaphor use in the said British journal (e.g. Charteris-Black, 2000; de los Rios, 2010; Koller, 2004, to name but a few). The studies carried out so far - mostly case studies - attest, among other things, to the scope and, at times, complexity with which the newspaper attempts to (re)construct various affairs of public interest and to inculcate its favorite ideologies into the mind of the reader. The Economist is so rich in political metaphor that even its editorial board, as is self-evident from their issued policy of metaphor use, consciously utilize 'new' metaphors in their articles (See e.g., "Metaphors we do everything by?" The Economist, May 26, 2011).

One goal, therefore, of this piece of research is to lay bare, as already mentioned, the modes through which the salient metaphorical patterns in the articles dealing with Iran's nuclear contention help justify and intensify the paper's professed policies, and background or deplore other alternatives facing the country's nuclear program future. In other words, the current research sets out to answer the following broad question as far as the data in this small-scale investigation are concerned:

What arguments against Iran's nuclear plans are embedded or implied in The Economist's use of political metaphors?

\section{A note on the concept of (political) metaphor}

Nowadays one can clearly see for themselves that the concept of 'metaphor' and our conception of it have undergone a sort of paradigmatic shift - something which is not dissimilar to what has happened to our conception of the dichotomous 'signifier-signified' relationship in post-structuralist linguistic and philosophic thinking. As a matter of fact, the concept is not so innocent as it was once thought to be and is still thought by most literary figures:

Metaphor ... is not a mere reflection of a pre-existing objective reality but a construction of reality, through a categorization entailing the selection of some features as critical and others as non-critical ... metaphors can consciously be used to construct ... reality (Goatly, 1997, p.5).

The impetus for this shift in our conceptualization of metaphor workings has been brought about in particular by the publication of Lakoff and Johnson's seminal book Metaphors We Live by (1980) and other follow-up publications (Lakoff \& Johnson, 1999; Lakoff \& Turner, 1989). With a cognitive take on the issue, the authors put forward the view that metaphor helps shape our view of reality. In the words of Lakoff (1993),

... the locus of metaphor is not in language at all, but in the way we conceptualize one mental domain in terms of another. The general theory of metaphor is given by characterizing such cross-domain mappings. And in the process everyday abstract concepts like time, states, change, causation, and purpose also turn out to be metaphorical. (p. 203).

Simply put, Lakoff and Johnson (1980) conceive of metaphor (or, more accurately, conceptual metaphor) as to the mapping of one domain of experience which is usually abstract onto a new domain of experience which is more concrete. This correspondence between the two domains (source and target) forms the backbone of metaphor theory in cognitive linguistics and psychology. For instance, the oft-quoted conceptual metaphor LIFE IS A JOURNEY can be conceived of as consisting of a source domain (JOURNEY) and a target domain (LIFE).

Thus a look at the views of metaphor theorists - from Aristotle, who considered it to be a mere literary device through the views of the Iranian Jorjani to Lakoff (1987), who broke the ground with his attribution of meaning-making function to metaphor to the more recent views of Chilton (2003) on the nature of political metaphor in political discourse shows the force of our proclaimed statement that a new paradigmatic thinking vis-à-vis metaphor has replaced our old way of conceiving of metaphor.

What is mostly and immediately relevant to the present piece of research is the 'reasoning' function of 'political metaphor' as highlighted by Chilton (2003):

Cross-domain metaphorical mappings make it possible to draw inferences that could not be drawn on the basis of direct evidence or the basis of direct experience. In political discourse metaphors are often not just embellishments of literal propositions, but modes of reasoning about, for example, the future and about policies. (p. 203).

The bottom-line of Chilton's assertion is that metaphors can be used, in effect, in political discourse to serve the purposes of those in power - to justify the courses of action or decisions they take, and, by the same token, to show as unwanted, irrational, odd, illegitimate, etc. as possible those taken by the so-called outsiders, enemies or minorities. This is reminiscent of the oft-quoted remark by Paivio (quoted in Mio 1997): "Metaphor is a solar eclipse. It hides the object of study and at the same time reveals some of its most salient and interesting characteristics when viewed 
through the right telescope" (p. 150). This "hiding-as-it-reveals quality of metaphor" (Mio, 1997, p. 150) is a much exploited function of much of the political discourse.

As far as the present research is concerned, it aims at analyzing a body of political discourse in the form of articles taken from The Economist having to do with Iran's nuclear power contention in the light of how an elite group i.e., the editorial board of the said paper, attempt at legitimating their professed policy of opting for more sanctions against Iran and delegitimating the Iranian camp's pursuing its nuclear 'ambitions'. If there is a contribution to the field and undertaking of metaphor analysis in this paper it is in seeing political metaphor specifically used by a typical Western paper with a critical eye.

\section{Data and Method}

This small-scale qualitative study is based on an aggregate of 30 argumentative, and at times, expository articles randomly chosen from The Economist, all on the subject of Iran's nuclear power program, fifteen of which coming out between 2005-2006 (the time when Mahmoud Ahmadinejad started his first presidential term and announced a resumption of Iran's nuclear power program which was being pursued quite idly for some time by the so-called Reformists), and fifteen other articles published in 2012 and at the beginning of 2013 (the time when President Ahmadinejad's tenure is coming to an end but the hot-bottom issue of Iran's nuclear contention is once again hitting the headlines due to the relentless sanctions being applied on the country right now). The data of the study were accessed by the investigators searching the paper's website search engine. The key words sought on the website were Iran + Nuclear. The search yielded an aggregate of 74 available articles exclusively on the issue of Iran's nuclear program. It was decided that 30 articles be exposed to metaphor analysis. The starting point for the analysis of the data was locating the instances of occurrences of personification of Iran. The focus was then narrowed down so as to include the way Iran was envisaged in The Economist or the modes through which actions and policies associated with its nuclear enterprise were discussed. With regard to the first phase of data collection (the date spanning 2005-2006), the analysis eventually yielded, apart from the higher-order metaphorical pattern IRAN AS A HUMAN, three specific lower-order metaphors i.e., IRAN AS A RACER/PLAYER, IRAN AS AN ILL HUMAN/A SUFFERER, IRAN AS A SUSPECT/CULPRIT, and IRAN AS A BARGAINER. With some overlap with the said categories of the first phase, the second phase of the study revealed, in addition to the higher-order metaphor IRAN AS A HUMAN, three more specific patterns, to wit, IRAN $A S$ AN ILL HUMAN, IRAN AS A WROGNDOER, and IRAN AS AN UNWANTED GUEST/A TRESPASSOR. In what follows we will provide some notable instances of each submetaphor and try to discuss one important purpose which those metaphors effectively serve in the newspaper texts, that is, legitimation and rationalization of sanctions against Iran, and delegitimation of the country's top figures' actions and decisions to further their nuclear activities. In the remaining part of this article, the target domain is Iran, or more specifically, the Iranian government but the source domains pertains to areas with negative and deplorable overtones such as offense and fraud, disease and pain, and even imposition.

\section{Patterns of metaphor use in The Economist (the $1^{\text {st }}$ phase 2005-2006)}

Patterns of metaphor use in the first phase of data analysis show a country rendered by the Western media as a 'rogue regime'. Not only do they represent Iran in a negative way but also they attempt at showing the country's nuke plans as irrational and unwarranted.

\subsection{IRAN AS A RACER/PLAYER}

The Economist as a Western paper with its unambiguously promulgated policy of applying more sanctions on Iran to quit its nuclear program envisages the country, time and time again, as a racer set on 'crossing the red line' and finishing its nuclear ordeal achieving nuclear bomb - something which is taken a dim view of by the Westerners. Hence the illegitimacy of Iran's attempts at furthering its nuclear plans. To the eyes of the paper, this racer must be stopped one way or another. At other times, the country is depicted as a player killing time and taking the speed out of the nuclear talks so it can 'speed up' its 'clandestine' nuclear activities. At any rate, Iran must be prevented from either its delay tactics or its rush for 'building the bomb':

\section{Excerpt 1}

But Mr Bush will not be keen to conciliate a hostile state that seems only to be accelerating its quest for nuclear weapons (The Economist, April 12, 2006, p.4).

\section{Excerpt 2}

However, the 50,000-centrifuge commercial plant being built nearby would speed things up a lot (The Economist, January 12, 2006, p.2).

\section{Excerpt 3}

... Iran this week strengthened suspicions that it is trying to build a nuclear weapon and shifted its confrontation with America into a higher gear... It was a step, said both the Americans and the Russians, in the wrong direction (The Economist, April 12, 2006, p.1). 


\section{Excerpt 4}

Iran has so far played a shrewd and winning hand both in Iraq and in its nuclear game of cat-and-mouse with America, Europe and the International Atomic Energy Agency (The Economist, January 12, 2006, p.1).

\subsection{IRAN AS A BUSINESSMAN}

The country is also shown as involved in a highly competitive business with other countries, in effect, those in the Western hemisphere or their allies and like-minded nations as far as they opt for a 'tightening' of sanctions on Iran. This usually occurs in two cases: either the country is depicted as bringing (financial) loss to itself, or as being implicated in bargaining over its nuclear program:

\section{Excerpt 5}

But without real costs to weigh against its nuclear plans, Iran will have little reason to consider the suspension of uranium enrichment and plutonium dabbling ... (The Economist, June 15, 2006, p.1).

\section{Excerpt 6}

The country's supreme leader ... who has the final say on anything important, threatened to block oil from leaving the Persian Gulf if Iran felt, in the course of bargaining, that the sticks outweighed the carrots (The Economist, June 8, 2006, p.1).

\subsection{IRAN AS A SUFFERER}

The articles analyzed in the present study reveal a plethora of metaphors having to do with the fact that the country is under much 'pressure'. Specifically, Iran is shown to be a person on the verge of suffocation. These metaphors are mostly employed by the paper to point to the force and effectiveness of the sanctions thus justifying the need for putting more restrictions on Iran:

\section{Excerpt 7}

But making such a cordon tight and effective would be hard, especially without full support from Iran's neighbours, argues Michael Knights in a recent paper for NPEC. Meanwhile Iran has already hinted that if push came to shove, it would not be shy of using its own weapons (The Economist, August 18, 2005, p.3).

\section{Excerpt 8}

Iran has already been growling about disrupting oil supplies through the Gulf. If pushed, it could end co-operation with the IAEA (The Economist, September 8, 2005, p.3).

\subsection{IRAN AS A SUSPECT/CULPRIT}

Still at other times Iran is portrayed as a country which cannot or should not be trusted with its nuclear undertaking. This is mostly realized in the form of legalizing metaphors giving a stark view of the country and its politicians or through fire metaphors showing specially the Iranian President as a deplorable figure wreaking havoc in several parts of the world by its extreme view as claimed by The Economist. Here the core argument employed by the British paper would read as: Since Iran is a country notorious for or involved in all kinds of wrongdoings, its nuclear ambitions should be curbed:

\section{Excerpt 9}

IN LESS than a month's time, Iran's new government, which has yet even to be sworn in by parliament, could find itself in the dock at the UN Security Council for restarting nuclear work ... (The Economist, August 18, 2005, p.1).

\section{Excerpt 10}

Meanwhile, Iran's fiery president, Mahmoud Ahmadinejad, has been gambling that Russia will do the same for him, by helping his regime to avoid paying any real price for its nuclear defiance (The Economist, December 19, 2006, p.2).

\section{Patterns of metaphor use in The Economist (the $2^{\text {nd }}$ phase 2012-2013)}

The second phase of data analysis having to do with the articles on Iran's nuke program spanning from 2012 onward is quite telling of the effects of relentless sanctions on Iranian politicians and the masses. The metaphorical words and clusters used in this section all aim at delegitimating the country's nuclear plans and futility of pursuing them. 


\subsection{IRAN IS A WRONGDOER}

The Western paper renders Iran in its articles, in the form of the device of personification, as a wicked yet miserable human being. The ill intention of Iran is shown, inter alia, through a range of metaphors having to do with criminality and double-dealing. Here the main function of the device is, without doubt, that of delegitimating Iran's nuclear plans. The obligatory part of the argument, or to borrow Wodak's (2001) favorite rhetorical term, topos, is as follows: Since Iran is a culprit, it follows that it cannot be trusted and must not be allowed to pursue its nuclear 'ambitions'. This scenario is represented and enforced, at times, by an abundance of legalizing metaphors:

\section{Excerpt 11}

Less publicly, Iran has shown that it is beginning to be rattled by increasingly punitive international sanctions (The Economist, March 10, 2012, p.1).

\section{Excerpt 12}

It was Mr Ahmadinejad's fifth trip to the region since 2005, and has inflamed fears in the United States that Iran may be building a terrorist network on its doorstep (The Economist, January 14, 2012, p. 1).

\section{Excerpt 13}

For years Iran has practiced denial and deception; it has blustered and played for time. All the while, it has kept an eye on the day when it might be able to build a nuclear weapon (The Economist, February 25, 2012, p 1).

\subsection{IRAN IS A PATIENT}

Another set of metaphors show Iran as an ill human or one suffering injury or torture. These closely related metaphors are realized in the data in several ways: through verbs belonging to the semantic field of hitting, through frequent metaphors of pressure (See the original study), and metaphors of pain and illness. The core argument would read as: Since Iran is becoming weaker and weaker, especially from within, the course of action advocated by the British paper i.e., imposing more sanctions on the country, should be pursued to its full effect. Another line of argument runs this way: Since Iran has an ailing economy and the country is suffering many problems, it behooves well if it caters for the material needs of its citizens rather than opting for its highly contentious and eventually disastrous nuclear program:

\section{Excerpt 14}

The Islamic Republic is enfeebled by corruption, inefficiency and the institutionalized disdain of those in authority for the people they rule. All of these ills have been fostered by ... dictatorial approach. In the Iranian body politics, the ... leader is both the virus and vaccine (The Economist, May 5, 2012, p. 2).

The above extract gives a stark image of the internal affairs of the country by drawing an analogy between a country beset by many social woes, where man on the street is left out in the cold, with an infected body. Such a country must, in the eyes of the editorial staff of The Economist, set priorities whose aim is to see to the welfare of its citizens rather than implicating itself more and more in its contentious nuclear undertaking. Sanctions, unless taken prudently care of by the Iranian government, will worsen the economic status of the country and it follows that Iranian families will suffer due to its ill effect:

\section{Excerpt 15}

No one said they would ease, any time soon, the crippling economic sanctions aimed at thwarting Iran's nuclear ambitions (The Economist, April 12, 2012, p.1).

\section{Excerpt 16}

This project, too, is stalled, and without another injection of government financing it could become one more casualty of the sanctions (The Economist, April 21, 2012, p.2).

\section{Excerpt 17}

International sanctions have bitten hard - creating a "world of hurt" in President Barack Obama's words (The Economist, May 19, 2012, p.1). 


\section{Excerpt 18}

America's chokehold on Iran's oil trade is tightening (The Economist, June 23, 2012, p.1).

\subsection{IRAN IS AN UNWANTED GUEST}

Still some other personifying metaphors have depicted Iran as a trespasser ('gatecrasher') and a guest not wanted in the arena of international business and politics by other countries, thereby rendering the country as a political 'pariah'. Again as (de)legitimatory metaphors, they are predicated on a specific argument: Since Iran is viewed with mistrust by the world community, it behooves well not to allow the country to keep up with its 'secret' nuclear program. By the same token, applying more pressure on it is warranted in the eyes of the newspaper staff:

\section{Excerpt 19}

There are not many places in the world these days where Mahmoud Ahmadinejad can count on red-carpet treatment. So his five-day visit this week to Latin America was an opportunity to show that Iran still has some allies ... (The Economist, January 14, 2012, p.1).

\section{Excerpt 20}

Nobody should welcome the prospect of a nuclear-armed Iran (The Economist, February 25, 2012, p.1).

\section{Excerpt 21}

The country is insecure, ideological and meddles in its neighbour's affairs (The Economist, February 25, 2012, p.2).

\section{Excerpt 22}

Indeed, an important international-payments system - the Society for Worldwide Interbank Financial Telecommunications, or SWIFT - has already kicked out 40 Iranian banks, after pressure from America (The Economist, June 23, 2012, p.2).

\section{Concluding Remarks}

This study set out to consider the metaphorical mappings found in a small body of data taken from a highly influential Western paper in portraying Iran's nuclear efforts. It identified seven major metaphors in the articles manipulatively employed by the newspaper. Looking at the vast range of strategies of negative other-presentation employed by The Economist with regards to depicting the Iranian side, as worked out by the antecedent to this follow-up study, it can be stated that the Western paper, as alluded to earlier, quite consciously and systematically employs and manipulates metaphor to achieve two purposes the second of which is the sole focus of the present investigation. The first metaphorical function dealt with in greater detail in the previous study is the representational (or, as Wodak puts it, nominational/predicational) role, and the second function (as yet apparently not fully exhausted in research and therefore warranting a special academic attention), not unrelated to the first one, is the justificatory power of metaphor abundantly found in most political discourses. Attending to political metaphor, viewed either as traingulatory data or as a triangulatory analytic tool, can help not only with giving more credence to research undertaken in Critical Discourse Studies but also give a fuller picture of the vast array of manipulative stylistic and linguistic moves used by the media to drive home a specific ideology while marginalizing other competing or adversative viewpoints. We conclude the article with Mio's comments on the functions of political metaphor and its workings on the way 'the public' come to see political metaphor:

Such linguistic devices are important - even necessary - tools of political discourse because political events are abstract and too numerous for public consumption. Metaphors allow the general public to grasp the meanings of political events and feel a part of the process. They are also effective because of their ability to resonate with latent symbolic representations residing at the unconscious level.

$(1997$, p.130)

\section{References}

Charteris-Black, J. (2000). Metaphor and vocabulary teaching in ESP economics. English for Specific Purposes 19, (2),149-165.

Chilton, P. (2003). Analysing political discourse: Theory and practice. London: Routledge.

De los Ríos, M. (2010). Cognitive devices to communicate the economic crisis: An analysis through covers in The Economist. Ibérica 20, 81-106.

Goatly, A. (1997). The language of metaphors. London: Routledge. 
Koller, Veronika. (2004). Businesswomen and war metaphors:'possessive, jealous and pugnacious'?." Journal of Sociolinguistics 8, 1, 3-22.

Lakoff, G. (1987). Women, fire, and dangerous things: What categories reveal about the mind. Chicago: University of Chicago press.

Lakoff, G. (1993). The contemporary theory of metaphor. In A. Ortony (Ed.), Metaphor and thought (pp. 202-251). Cambridge University Press.

Lakoff, G. \& Jonson, M. (1980). Metaphors we live by. Chicago: University of Chicago Press

Johnson, M., \& Lakoff, G. (1999). Philosophy in the flesh: The embodied mind and its challenge to western thought. New York: Basic Books.

Lakoff, G., \& Turner, M. (1989). More than cool reason: The power of poetic metaphor. Chicago: University of Chicago Press.

Metaphors. (Retrieved June 5, 2012 from http://www.economist.com/style-guide/metaphors).

Metaphors: Metaphors we do everything by? (2011) (R. L. G.). Retrieved June 5, 2012 from http://www.economist.com/blogs/johnson/2011/05/metaphors.

Mio, J.S (1997). Metaphor and politics. Metaphor and Symbol 12, 2, 113-133.

Nuclear Iran: Not quite too late. Retrieved April 7, 2012 from http://www.economist.com/blogs.

Rasti, A., \& Sahragard, R. (2012). Actor analysis and action delegitimation of the participants involved in Iran's nuclear power contention: A case study of The Economist. Discourse \& Society, 23(6), 729-748.

Wodak, R. (2001). The discourse-historical approach. In R. Wodak \& M. Meyer (Eds.). Methods of critical discourse analysis (pp. 63-94). London: SAGE. 